\title{
Bioprocess Control: Current Progress and Future Perspectives
}

\author{
Anurag S. Rathore* ${ }^{\mathbb{D}}$, Somesh Mishra, Saxena Nikita and Priyanka Priyanka
}

Department of Chemical Engineering, Indian Institute of Technology Delhi, New Delhi 110016, India; somesh25162@gmail.com (S.M.); saxena.nikita27@gmail.com (S.N.); priyanka.dalal24@gmail.com (P.P.)

* Correspondence: asrathore@biotechcmz.com

Citation: Rathore, A.S.; Mishra, S.;

Nikita, S.; Priyanka, P. Bioprocess

Control: Current Progress and Future

Perspectives. Life 2021, 11, 557.

https://doi.org/10.3390/life11060557

Academic Editors: Augusto

Quaresma Henriques Pedro, Mara

G. Freire, Fani Pereira de Sousa and

Patrícia Alexandra Nunes Pereira

Received: 28 May 2021

Accepted: 10 June 2021

Published: 13 June 2021

Publisher's Note: MDPI stays neutral with regard to jurisdictional claims in published maps and institutional affiliations.

Copyright: (C) 2021 by the authors Licensee MDPI, Basel, Switzerland. This article is an open access article distributed under the terms and conditions of the Creative Commons Attribution (CC BY) license (https:/ / creativecommons.org/licenses/by/ $4.0 /)$.

\begin{abstract}
Typical bioprocess comprises of different unit operations wherein a near optimal environment is required for cells to grow, divide, and synthesize the desired product. However, bioprocess control caters to unique challenges that arise due to non-linearity, variability, and complexity of biotech processes. This article presents a review of modern control strategies employed in bioprocessing. Conventional control strategies (open loop, closed loop) along with modern control schemes such as fuzzy logic, model predictive control, adaptive control and neural network-based control are illustrated, and their effectiveness is highlighted. Furthermore, it is elucidated that bioprocess control is more than just automation, and includes aspects such as system architecture, software applications, hardware, and interfaces, all of which are optimized and compiled as per demand. This needs to be accomplished while keeping process requirement, production cost, market value of product, regulatory constraints, and data acquisition requirements in our purview. This article aims to offer an overview of the current best practices in bioprocess control, monitoring, and automation.
\end{abstract}

Keywords: process monitoring; control systems; neural networks; fuzzy logic; automation; bioprocess control; open loop; closed loop

\section{Introduction}

Biopharmaceuticals or biologics have dominated the healthcare sector over the past decade [1]. This class of biotherapeutic products includes proteins, monoclonal antibodies (mAbs), and nucleic acids (DNA, RNA or antisense oligonucleotides) [2]. The success of these products is attributed to their effectiveness towards treating and managing a variety of otherwise hard to treat diseases including cardiovascular, neurological, cancer and other rare diseases. In 2017, the global market of biologics was USD 186.470 billion, and is expected to reach USD 526.008 billion by 2025 at a compound annual growth rate (CAGR) of $13.8 \%$ [3]. Within biotherapeutic products, mAbs are the most successful due to their success as therapeutics and for diagnostics [4]. The total global market of mAbs was over USD 122 billion in 2019, and is expected to surpass USD 200 billion in 2024 at CAGR of $6.9 \%[5]$.

Fundamentally, bioprocess development is performed while taking into account the nature of the host cell, microbial or mammalian. Often, the complex non-linear cellular growth and product kinetics are determined by the highly complex cellular metabolic network, ultimately impacting process yield and product quality [6-9]. The biologic manufacturing platform comprises of multiple upstream and downstream unit operations with the former including cell culture, cultivation, and harvesting unit operations, and the latter including multistep chromatography, filtration, and diafiltration [10].

Bioprocess productivity can be improved by efficient process control. Any control structure requires a sensor to detect deviation in a critical quality attribute (CQA) or a critical process parameter (CPP), monitoring recipe to decide when is it necessary to take action, and last but not the least, control logic for manipulating process variables to achieve the desired change and verification that the manipulation is effective and in right direction [11,12]. The past few decades have witnessed considerable contributions 
to process modelling, whether mechanistic, stochastic, or empirical [13-15]. Additionally, considerable advancements have been achieved in process control, with adaptive control, fuzzy logic, and neural networks to name a few.

The selection of feedback control strategy depends on the complexity of system. If the system is just to be maintained at a static set point, then the use of computationally inexpensive proportional-integral (PI) control may be sufficient. More advanced control algorithms are needed for dynamic signal tracking or for control of complex systems. Irrespective of the computationally expensive nature of these algorithms, they have the potential to accurately capture the altercations of the desired metabolic pathways. These pathways contained complex regulation networks and thus show highly nonlinear behaviours. Recently, various digital approaches such as artificial intelligence (AI) for advanced monitoring and control and computational models have been implemented to study molecular or process-relevant behaviour [16-18].

Moreover, one of the guiding principles of quality by design $(\mathrm{QbD})$ is to incorporate the use of modern control strategies and process analytical technology (PAT) tools so as to deliver consistent process performance and product quality $[19,20]$. QbD implementation involves identification of critical quality attributes (CQAs), comprising of physical, chemical, biological properties and other characteristics that need to be maintained in the desired limit, range or distribution [21]. Additionally, each CQA is influenced by critical process parameters (CPPs) whose fluctuations and effect over CQA must be supervised and control. PAT has been defined as "a system for designing, analysing, and controlling manufacturing through timely measurements (i.e., during processing) of critical quality and performance attributes of raw and in-process materials and processes, with the goal of ensuring final product quality" [22]. A key goal of PAT implementation is to design a process that can handle incoming variability to deliver consistent product quality [23].

In this review, we present a discussion of control strategies applied for control of bioprocesses. A variety of control schemes including feedback control, feedforward control, cascade control, and advanced control techniques have been addressed. It has been elucidated how an optimal control scheme aims to seek a compromise between bioprocess dynamics (well understood concepts) and bioprocess kinetics (less understood concepts). Challenges faced during implementing advanced control strategies are also highlighted.

\section{Sustainability in Biologic Manufacturing}

Before discussing bioprocess control strategies, we would like to briefly explore the concept of sustainability in biologic manufacturing. The control strategies should be developed in a way that they complement sustainability. Over past decade, the perception of sustainability has evolved to describe such conditions that enable peaceful existence of industry with nature while meeting present and future generation socioeconomic demand [24,25]. In sustainable biologic manufacturing, the existing economic and environmental challenges need to be effectively managed. It requires an assessment framework comprising of qualitative indicators from life cycle assessment (LCA) and techno-economics analysis (TEA) to optimize biologic manufacturing at the preliminary stage itself $[24,26]$. It allows us to identify trade-offs across environmental and economic aspects over the entire process of biologic manufacturing.

For decades, LCA is known as a standard approach in many commercial industries. However, its potential is yet to be fully realized in biologic manufacturing. Few studies have highlighted the importance of LCA and TEA for designing more cost-efficient, robust and environmentally friendly biologic manufacturing processes. In one study, Biosolve simulation tool has been implemented to conduct LCA analysis of the mAb manufacturing process. Here, the CIP and SIP steps are found to have greater environmental impact in the same study [26]. Another study assesses the process development and production cost across biopharmaceutical product cycle along with their contribution in overall research and development ( $R$ \& D) cost [27]. The utilization of single use technology has been suggested to be economically favourable for short term and small-scale production (such as 
clinical production) [28]. For life cycle inventory, software such as Biosolve and Superpro Designer are utilized to model a new production line in combination with LCA software GaBi [29]. LCA in conjunction with TEA helps in accessing and optimizing sustainability performance in terms of environment and economics of biologic manufacturing. It allows us to identify hotspots (major environmental problems or costs) that may occur and how changes in life cycle inputs (resources used) and outputs (emissions into the environment) can reduce such hotspots. Further, LCA can take into account environmental impact of process as a whole which make it an ideal decision support tool to improve the decisionmaking quality in biologic manufacturing.

\section{Strategies for Bioprocess Control}

Bioprocess control comprises of a set of operations that supervise the process in an unpredictable environment with the objective to maintain the process within the desired design space. Typically, the control strategy is created during process development. Creation of a robust control strategy depends on how deep our understanding of the process is and if we have accurate process models. Inaccurate process models are known to result in instability of the controller [30]. Another major challenge is that of data availability as often limited data is available during process development [30,31]. There is a direct relation between the level of process understanding and the degree of robustness of the control system (Figure 1). Table 1 lists the different strategies implemented for bioprocess control along with their control structures. Depending on the requirements, one can decide on the optimal choice between selecting sophisticated instrumentation and complex control laws or simple control law with elaborate monitoring system.

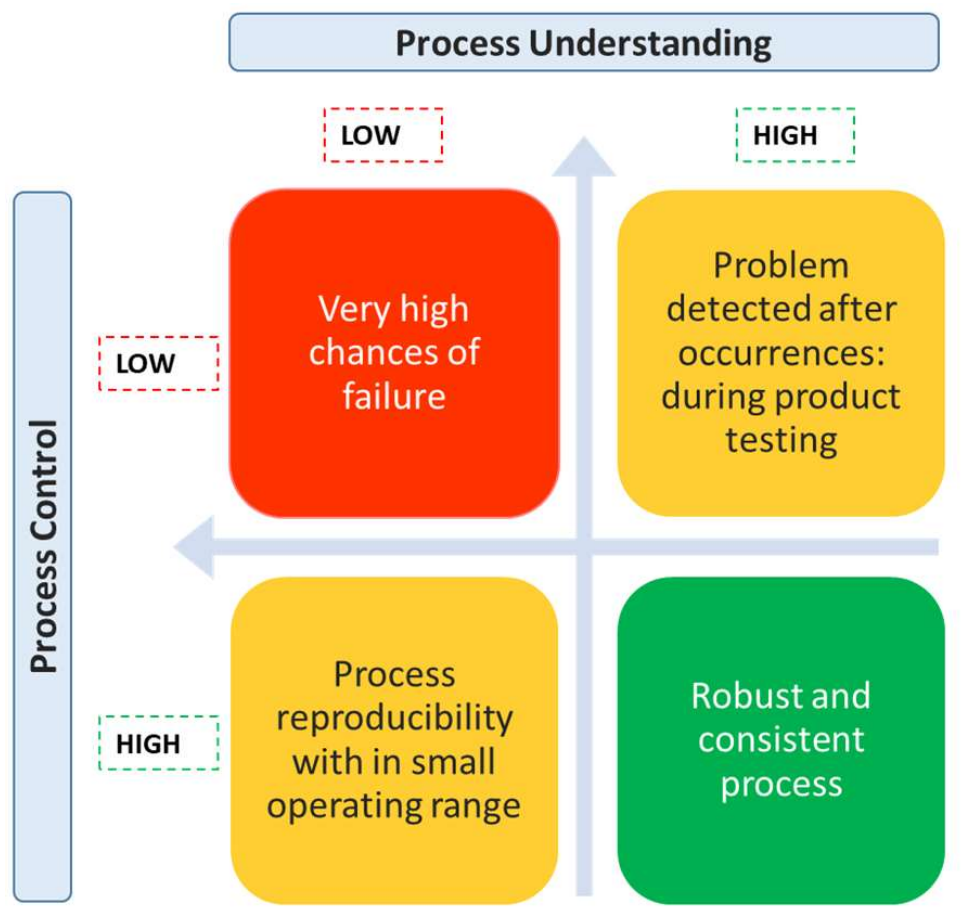

Figure 1. Importance of process understanding and controller for process development. 
Table 1. Description of different control strategies and their control structures.

\begin{tabular}{lll}
\hline \multicolumn{1}{c|}{ Control Strategy } & \multicolumn{1}{c}{ Description } \\
\hline Pre-computed and sequential \\
control actions are stored in a \\
controller and executed on demand \\
Control action cannot be adjusted \\
based on system \\
response/disturbance \\
Open loop control strategy can only \\
give instruction to the equipment \\
No means of data acquisition
\end{tabular}

- Input to the primary loop process transfer function is obtained from the output of secondary loop process transfer function

- The presence of "secondary" Cascade control measured process input variable checks the emergence of primary disturbance. This improves controller performance by lowering both the maximum deviation and the integral error for disturbance

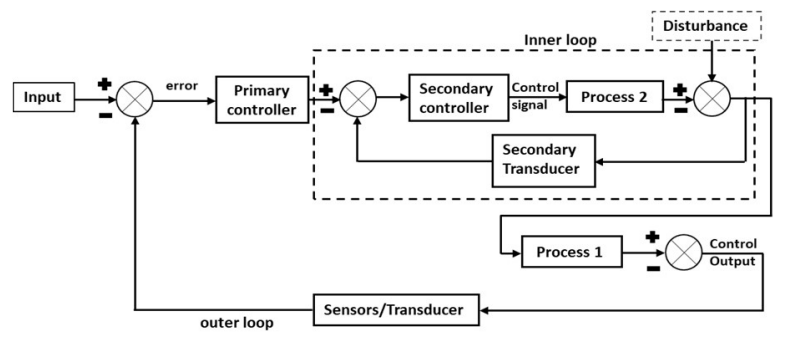
responses

Fuzzy logic-based control
- $\quad$ Flexible reasoning method that imitates human decision making based on IF- ELSE protocol

- It comprises of 4 modules: Fuzzification, Knowledge based, Inference system, and Defuzzification

- Can be applied in case of imprecise domain knowledge with distorted and noisy data

- Limitation includes dependency on human knowledge and experience, low accuracy, no systematic approach to problem solving, and requirement of regular updates of fuzzy rules for the controller to remain effective

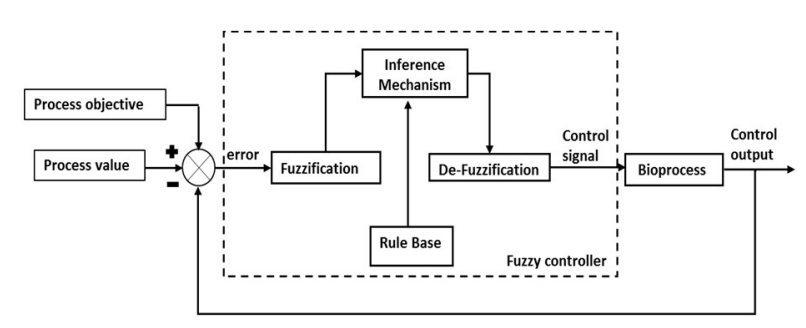


Table 1. Cont.

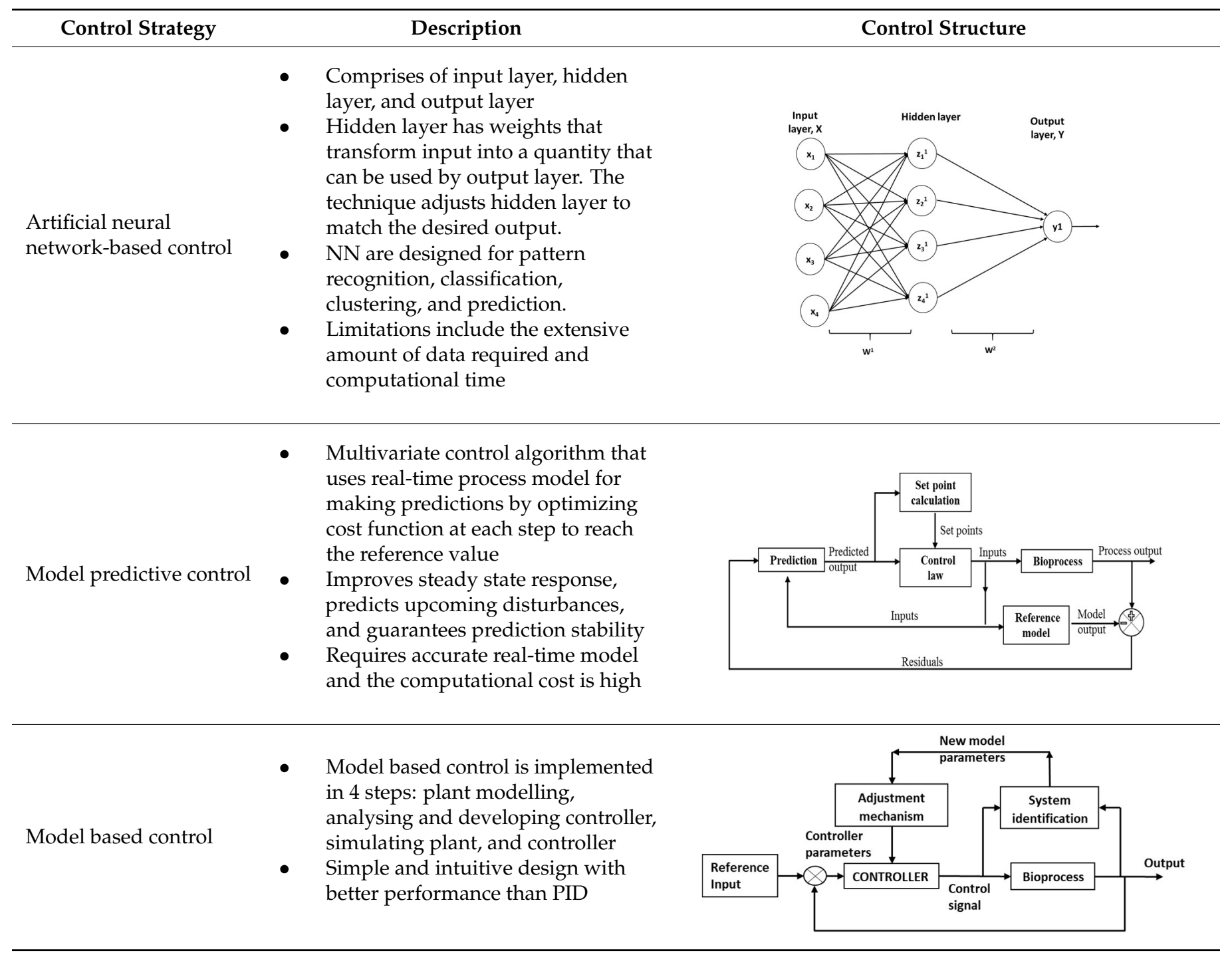

\subsection{Open Loop Control}

This is the simplest and oldest control technique and has been employed for several carbon-limited fermentation processes at industrial scale [32]. Here, online measurements are not required and hence, the strategy is unable to dismiss any disturbance in the system. Researchers have utilized the open loop control strategy to reduce batch-to-batch variability [33]. The predefined operating condition, based on the initial operating parameters, acts as the input to the system. In numerous studies, predetermined exponential feed profiles (calculated based on initial conditions and growth kinetic parameters) are reported $[33,34]$. In recent studies, optimization of fed-batch operating conditions based on open loop strategy have been reported for recombinant lipase B, vaccine synthesis, ethanol, and poly (3-hydroxybutyrate-co-3-hydroxyvalerate) production [34-38].

While open-loop control strategies have been successfully used for bioprocess control, significant limitations exist including requirement of pre-computed knowledge of profiles, difficulty in mathematical formulation of non-linear systems, challenges with respect to realtime application, and requirement of complex databases of the process [32-34]. Another major limitation is the incompetency to take corrective measures if random disturbances occur during process operations [39]. 


\subsection{Proportional Integral/Proportional Integral Derivative (PI/PID) Control}

Closed loop control systems, such as PI and PID, are designed to overcome the disadvantages of open loop control. In such a system, a feedback term is added for regulatory action to offer closed loop control. Hence, the control law becomes the sum of feedforward and feed backward terms. The most common closed loop algorithm is the PID controller, owing to its simplicity, robustness, and ease in tuning. Recently, researchers have developed a SISO nonlinear bioreactor model using real-time data of $E$. coli fermentation and employed internal model control based PID (IMC-PID) [40]. It is seen that the proposed IMC-PID method resulted in superior performance with minimum absolute error when compared to other methods [40]. The real-time investigation of closed loop depicted satisfactory tracking of the set point levels. Similar studies conducted using IMC-PID controller for temperature control in CSTR during ethanol production gave better results [41]. For another application involving improvement in biomass growth, combination of PI control with Generic Model Control (GMC) technique is implemented to fed batch cultivation of E. coli BL21(DE3). The proposed approach satisfactorily tracks the biomass profile with controller capable to maintain relevant growth conditions [42]. Feedback control loops such as flow feedback, $\mathrm{pH}$ feedback, or a combination of both have been applied for buffer preparation in inline conditioning and have shown significant potential $[43,44]$. For complex systems, PID control strategy has been modified as a nonlinear gain in sequence with a linear PID. In case the error between the set point and the real-time process variable is zero, the system behaves as a linear system otherwise as non-linear system. Considerable performance improvement has been observed with the proposed approach in case of regulatory control and set point tracking in closed-loop system [45]. Additionally, feedback PID control loops are employed for control of microbial culture wherein the culture composition is the input variable and the actuator influence population dynamics. Actuators can be $\mathrm{pH}$, dissolved oxygen, temperature or addition of inducer compounds that affects the organism's fitness. It is seen that simple feedback loop has enabled high reproducibility of processes with quality product [46]. Until now, such strategies are rarely experimented, but have a promising future [47].

While PI/PID based control offers optimal performance for linear processes, it has limited ability to cope up with non-linear processes [39,48]. Since the underlying physicochemical processes for most complex biotech unit operations are non-linear, these dated controllers are not suitable to the dynamically changing conditions that are observed in most biological systems and, hence, modifications are required to make the controller effective for non-linear processes.

\subsection{Cascade Control}

Cascade control systems are comprehensively used in industry to improve the dynamic response of the systems. They minimize the effect of load disturbance that are received in the secondary or slave loop. Few studies have demonstrated their application for processes where the transfer functions of the primary and secondary loop are parallel $[49,50]$. Performance of the cascade control system is better than the conventional single loop control due to the presence of multiple sensors to measure conditions in a controlled process [51]. Cascade control strategy is required when the single loop control strategy fails to deliver satisfactory control output and secondary variable measurement is possible [52]. In a way, it can be said that cascade control strategy is one step superior to PI/PID control.

Despite encouragement from the regulators, only a few academic researchers have tested the potential of cascade control in biopharma manufacturing. In one study, the bioreactor reproducibility both within and throughout culture stations (12 bioreactor vessels blocks) of AMBR 15 fermentation system (AMBR 15f) evaluated in fed-batch mode suggested cascade control strategy (air/stirrer/oxygen) as a better option for obtaining optimum cell growth [53]. Similarly, two-sided control loop for $\mathrm{pH}$ control is preferred in bioreactors [54]. Researchers have also attempted to control DO levels during aerobic fermentation using Pseudomonas putida mt-2 via cascade control [55]. Use of cascade- 
control to regulate DO levels during continuous fermentation for recombinant lipase B production resulted in 5.8 times higher productivity over fed-batch [34]. In another application, researchers demonstrated the effectiveness of cascade control for nullifying batch variation during biopharma production wherein the controller allowed short-time process disturbances (e.g., feed pump disturbances and antifoam spikes) to be resolved and yielded satisfactory batch reproducibility [56].

Advantages of cascade control that have been demonstrated include: (1) likely disturbance is distributed in the secondary loop where the corrective measures are taken without influence over primary loop; (2) the lag phase associated with the auxiliary process part is completely abated in the secondary loop and hence, improved the response of primary loop; (3) gain variation of the auxiliary part is subdued in the same loop; and (4) the secondary loop allows the primary controller to accurately regulate the mass or energy flow. Thus, applying the cascade control strategy for biotherapeutics production is likely to see increasing interest in the scientific community.

\subsection{Model Predictive Control}

Model predictive control (MPC) has been widely attempted for bioprocess optimization $[57,58]$. Its primary requirement is a predictive process model, through which the dynamic and static interactions among the input, output, and disturbance variables can be apprehended and the control estimate can be synchronized with the optimum set points calculations $[59,60]$. Successful implementation of MPC to track the variable trajectory $[49,61]$ and to maximize process variables has been reported in biomanufacturing $[62,63]$. Owing to the complexities and variabilities in mammalian bioprocesses, non-linear MPC (NMPC) with dynamic models has been successfully applied but with larger computational time $[64,65]$. However, this large computational time (up to several minutes) is acceptable for such processes due to the lengthy process time (typically in weeks). In addition, NMPC employed to address parametric uncertainties using min-max optimization coupled with unscented Kalman filter (UKF) resulted in better performance and also dealt with sensor unavailability issue for fed batch processes efficiently [66]. Researchers have also used MPC for real-time control of quality attributes [67]. In multicolumn counter current solvent gradient purification (MCSGP) process, MPC strategy successfully tracked system periodicity and rejected disturbances. The results obtained were in agreement with the experimentally optimized profiles [68]. Apart from this, single input single output (SISO) MPC and multiple input multiple output (MIMO) MPC when used for online estimation and control of the fed batch reactor have demonstrated better results than proportional integral controller and feedback/feedforward controller. Steady state stabilisation in oscillating cell culture bioreactors can be achieved by implementing MPC designed based on cell population balance models [69].

As the essence of MPC is based on the process model, whether mechanistic or stochastic, its success is also heavily dependent on the model's accuracy and its ability to handle the system disturbances $[30,32,70]$. Inaccurate process models are known to lead to faulty results $[25,48]$. In the case of data driven model, a large number of data points are required $[48,57,71]$. Further, the MPC approach is considered as computationally expensive in comparison to other control strategies, especially when optimization is required at each time step [69,72]. Thus, despite MPC being well established in chemical industries, its acceptance in biotech sector requires further development of robust process models.

\subsection{Neural Network-Based Control}

Application of neural networks (NN) is already established to solve complex tasks in different engineering, medical, and other domains [73]. Since NN can effectively deal with non-linear systems and has adaptive learning, its application in bioprocess monitoring and control is becoming increasingly popular. Usually, data availability is the biggest limitation in designing neural network. However, few researchers have developed an alternative option to overcome the data limitation by generating artificial datasets (incorporating 
random noise to original datasets). Such approach is used in modelling and optimization of fed batch process for cyanobacterial C phycocyanin production [74]. The results obtained were in par with the neural network designed using large dataset. Recently, an adaptive neural network technique is devised for tracking control. The method possesses a self-learning capability which gives an added advantage in case of unavailability of prior data [75]. In a similar study, closed loop controller designed with a neural network estimator for a nonlinear process resulted in minimum tracking error when compared to conventional open loop methods even in case of perturbations and parametric uncertainties [39]. It is seen that the method gives better accuracy and is simple to design. Different variants of neural network are useful in different cases. Use of radial basis function neural network for fed batch bioreactor gave satisfactory performance in case of time varying parameters, uncertain non-linear disturbances and unmodeled dynamics [76]. Researchers have demonstrated the prediction of fungal biomass through Multiphase Artificial Neural Network (MANN) model during the lag, log, and stationary growth phase. The result indicates successful prediction of nonlinear features of fed-batch bioreactors via the MANN model [77]. Monitoring transient state performance using ANN has been shown to offer a better approach for controlling variables [78].

It is seen that trained neural networks can effectively evaluate and monitor process variables. ANN in combination with extended Kalman filter gives improved predictions in real time. This structure overlayed by model predictive control has great potential in non-linear process control [79]. In another study, MLP3 neural network has been introduced for controller output regulation and optimization. The strategy was experimentally validated on alpha 1-antitrypsin (A1AT, human recombinant protein) production in Pichia pastoris expression system under the control of alcohol oxidase (pAOX1) and resulted in a significant improvement in product yield [80]. Apart from its role in control, NN offers significant potential in developing model for different unit operations, thus enabling model-based control.

Advantages of neural network over first principle or empirical modelling include: (1) NN's are more capable of dealing with high non-linearity; (2) the probability of higher structural complexity makes them more descriptive as compared to empirical models; (3) their structure needs not to be predefined; (4) they offer greater flexibility in modelling; and (5) NN's are less noise prone and can be applied to the systems of utmost uncertainty.

\subsection{Fuzzy Logic-Based Control}

Fuzzy logic inquisitively integrates human experience and reasoning that is fundamental to design nonlinear controllers. In a recent publication, researchers have reviewed the evolution of fuzzy logic [81]. Fuzzy logic-based controllers have found practical applications in wider areas of energy, medicine, material, economics and pharmacology sciences.

Application of fuzzy logic-based controllers for control and decision making in bioprocess industry is well established. Bioprocesses such as fermentation operations are complex and laden with various uncertainty factors. Therefore, the setup of optimum process parameters is necessary for achieving higher growth rates and productivity. Multiple researchers have demonstrated application of fuzzy logic Takagi Sugeno fuzzy controller for tracking control of bioprocess $[82,83]$. Here, the process was modelled using the TS fuzzy model followed by the use of fuzzy observer for designing controller. Two different control approaches were employed for output tracking, i.e., parallel distributed compensation control and fuzzy optimal control. It was seen that fuzzy control had lower root mean square error while dealing with the non-linearity of the system. Similar results were published for the purification of secondary metabolite optimization [84]. In addition, implementation of fuzzy feedforward control strategy for temperature control in fermentation [85] or product concentration control in enzymatic reactor [86] have proved to be efficient control logics for improving load rejections in non-linear process. An interesting application of fuzzy logic controller in combination with ANN is seen for fed batch cultures. In this study, ANN was used as a soft sensor to estimate the glucose concentration whereas 
fuzzy logic controller was implemented for controlling substrate addition. An improvement in estimation and control was observed with an error of $6 \%$ [87]. Several researchers have demonstrated applications of fuzzy control systems for control and optimization of bioreactor operations [88].

Fuzzy logic-based approaches have also been demonstrated to successfully explain the complexity of biological processes. The rules describing the expert process knowledge do not contain any complex mathematical equations and hence, are easy to understand. Thus, fuzzy systems can be considered as a special case of local modelling approach in which the input domain is distributed among different fuzzy regions described via multivariate membership functions [82]. However, the limitations associated with fuzzy logic systems are substantial and include inaccurate estimation of parameters due to fine tuning of rules, lack of adaptability for dynamic process state or minute process variables change that may have greater impact on overall process due to lack of learning. Thus, it is difficult to estimate continuous and independent optimization of operating variables via expert knowledge. These systems are more suitable for retaining distinct process space and quality aperture.

\subsection{Model-Based Control}

Process models provide the foundation of advanced process monitoring, optimization, and control. Such models can be mathematical, statistical, or empirical. Effective monitoring and control of processes through the use of mathematical models has been demonstrated by multiple researchers $[25,30,89]$. One such framework named parametric optimization and control (PAROC), which has been implemented for biopharmaceutical purification process, was developed using model-based control techniques. The platform consisted of system identification and model analysis followed by designing multi parametric model predictive control and resulted in satisfactory control [90-92]. Same methodology when applied to small scale chromatography systems also tested successful for steady state operations and in rejecting uncertain perturbations [93]. In addition, when extended it was applicable to pressure swing adsorption and simulated moving bed systems [94]. Following a similar approach for capture chromatography in integrated continuous processes, mechanistic model was established with the adaptive model predictive controller for design and control of the capture steps [95].

For the bioreactor, a number of control strategies have been applied. For example, DO-stat control strategy [96-101] and Extremum seeking control strategy [102-104]. DO stat or $\mathrm{pH}$ stat control strategies are based on the concept of indirect feedback control. Here, a simple on-off controller manipulates indirect variables if direct variable deviates. In DO stat control, concentration of dissolved oxygen is maintained constant whereas in $\mathrm{pH}$ stat control, the $\mathrm{pH}$ is maintained constant. Extremum seeking control, developed based on process models, solves optimization problem as control problem. It enhances system capability to reject disturbances and thereby reduces sensitivity and downtime. A recent case study demonstrates model-based control of end-to-end continuous process for manufacturing monoclonal antibodies. The upstream process included bioreactor integrated with ATF and downstream process included protein A capture, viral inactivation, cation and anion exchange chromatography integrated together. The proposed control strategy was capable of automation of the process for optimal operation $[105,106]$.

However, realization of overall process supervision and control based on mathematical model remains an exception in biotech manufacturing. This is due to insufficient process understanding arising from process complexity. The mathematical models developed are therefore primarily used for elementary processes. In combination with archival data, real-time data, and observer intelligence have been used to develop hybrid models (Figure 2) [107-110]. Researchers have developed a holistic model from fundamental relations, transfer functions and the data from $\mathrm{mAb}$ process to simulate a high titre production bioreactor. Except for ammonia and glutamine, the application showed $80 \%$ agreement between predicted and experimental data [111]. Thus, holistic based control architecture 
can integrate static and dynamic feedback components along with logic based switching or discrete event elements. Despite the advancements in the fuzzy and NNs control systems design, a control system that can cope with uncertainty and nonlinearity remains overdue. However, most of the attention towards the development of hybrid controllers has been focused on set point control and tracking problems.

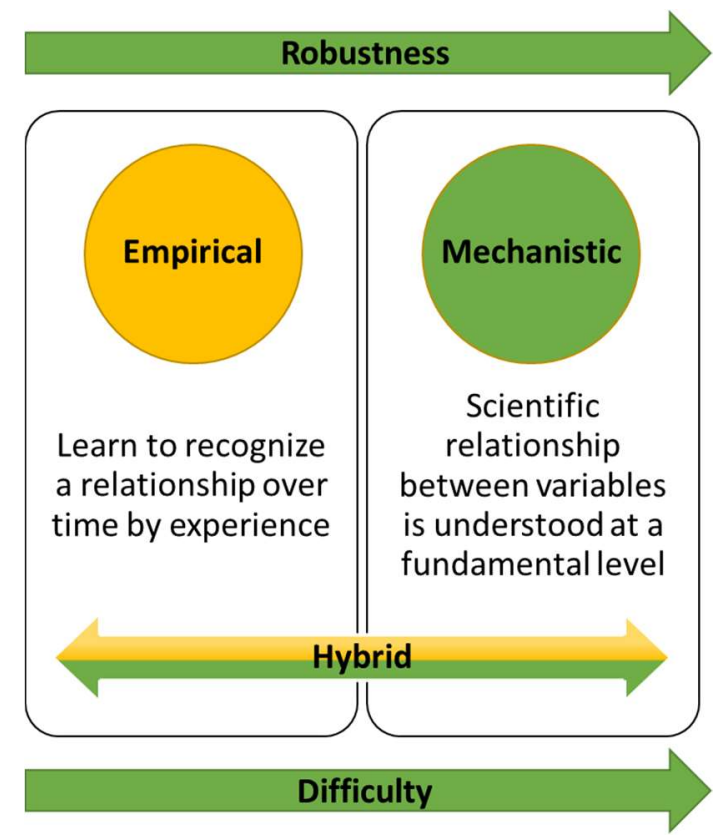

Figure 2. Example of hybrid model base bioprocess control.

\section{Future Scope}

\subsection{Soft Sensor-Based Control}

Considering the complexity of bioprocesses, modelling to capture the overall characteristics and variability remains a challenge. In bioprocesses, due to limited availability of reliable on-line sensors, majority of process variables are evaluated off-line or at-line, thereby resulting in an increase in overall system cost and delivery of inefficient information. Moreover, operation and calibration for long duration in agitated, harsh environment for online sensors and manual operation with varying frequency of measurement for at line sensors are additional challenges in acquiring data. This has led to development of cybernetical-physical systems wherein the integrated physical systems are controlled by soft sensors and algorithms (Figure 3). Soft sensors have emerged as potential tools for evaluation and maintenance of CQAs in on-line mode, thus enabling QbD [112-114]. Different studies have shown the uses of soft sensors for determination of biomass, product, metabolites, amino acid concentration, and other CQAs, thus enabling process control (Table 2). Although advancements in the soft sensors development are vast, their real-time implementation requires further the development of non-invasive analytical techniques, with the ability to monitor in situ or in real time; sensor devices adaptable in various production systems and make it certain that the sensor configuration adheres to regulatory compliances and good manufacturing practices. Real-time, user-friendly interfaces are required so that the connection and contextualization of information from different sensors can be made possible via digitalization [115]. 


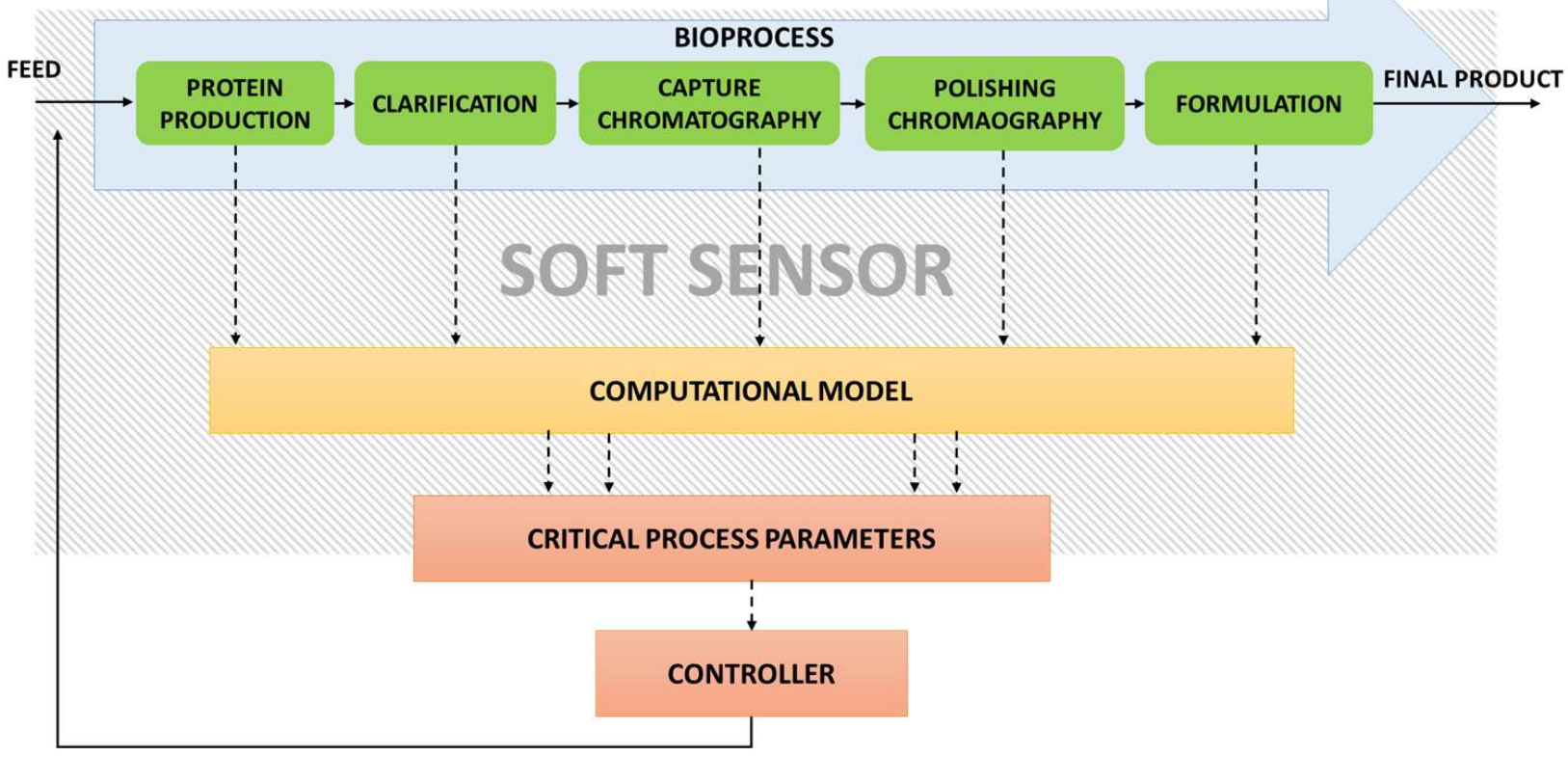

Figure 3. Soft sensor-based control set up for a generalised bioprocess.

Table 2. Cases studies on soft sensor development for various applications.

\begin{tabular}{|c|c|c|}
\hline Technique & Application & Reference \\
\hline Artificial neural network & $\begin{array}{l}\text { Monitor fermentation process-measurement of } \\
\text { glycerol, 1,2 propanediol and biomass }\end{array}$ & [116] \\
\hline $\begin{array}{l}\text { Multiple linear regression in combination with } \\
\text { mechanistic model }\end{array}$ & Prediction of biomass concentration & [117] \\
\hline Empirical models & Biomass concentration & [118] \\
\hline Empirical modelling of oxygen uptake rate & Predicted viable biomass & [119] \\
\hline $\begin{array}{l}\text { Multivariate adaptive regression spline algorithm } \\
\text { in combination with 2D fluorescence spectra and } \\
\text { process data }\end{array}$ & Biomass concentration & [120] \\
\hline Artificial neural network & Glucose estimation in fed batch culture & [78] \\
\hline Deep neural network & $\begin{array}{l}\text { Parameter estimation in penicillin and } \\
\text { streptokinase fermentation process }\end{array}$ & [121] \\
\hline $\begin{array}{l}\text { Partial least square regression with turbidity and } \\
\text { Raman measurements in combination with Monod } \\
\text { kinetics model }\end{array}$ & Predict substrate concentration & [122] \\
\hline Error propagation method & $\begin{array}{l}\text { Estimate error in predicted biomass fermentation } \\
\text { rate and substrate consumption rate }\end{array}$ & [123] \\
\hline $\begin{array}{l}\text { Partial least square regression in combination with } \\
\text { fluorescence fingerprinting }\end{array}$ & $\begin{array}{l}\text { Monitor biotransformation production of } 2 \text { phenyl } \\
\text { ethanol by yeast }\end{array}$ & [124] \\
\hline $\begin{array}{l}\text { Partial least squares regression model in } \\
\text { combination with Raman spectroscopy }\end{array}$ & $\begin{array}{l}\text { In line monitoring of the nutrient consumption } \\
\text { and production of markers associated with cell } \\
\text { metabolism }\end{array}$ & [125] \\
\hline $\begin{array}{l}\text { Partial least squares regression model in } \\
\text { combination with Raman spectroscopy }\end{array}$ & In line monitoring on amino acid & [126] \\
\hline $\begin{array}{l}\text { Partial least squares regression with the help of } \\
\text { mid-UV absorption spectra }\end{array}$ & Monitor chromatography steps & [127] \\
\hline
\end{tabular}


Table 2. Cont

\begin{tabular}{llll}
\hline \multicolumn{1}{c}{ Technique } & Application & Reference \\
\hline $\begin{array}{l}\text { Partial least squares regression with Fourier } \\
\text { transform mid infrared spectroscopy }\end{array}$ & Monitor HCP and aggregates at line & [128] \\
\hline Deep neural network & Lactose and ethanol concentration measurement & [129] \\
\hline $\begin{array}{l}\text { Linear regression on data obtained from } \\
\text { biocalorimetry in combination with bioreactor off } \\
\text { gas analysis }\end{array}$ & Biomass concentration measurement & [130] \\
\hline
\end{tabular}

Advancements in miniaturization of sensors, development of smart sensors, and approaches for hardware-software integration (digital highway like fieldbus/profibus or wireless) has given an extra advantage to its adoption in manufacturing. Industry 4.0 requires computer algorithm based monitoring and cyber-physical system control. If the connections between soft sensors and process system engineering is investigated thoroughly and carefully, then it can be said that with soft sensors, Industry 4.0 can become a reality in bioprocessing with a promising future [131,132].

\subsection{PAT Based Control Strategies}

The task of the controller is to manipulate the process variable in a way that the disturbance effect can be minimized and the process variable follows the specified trajectory. As discussed in the previous sections, traditional feedback PI controllers are widely implemented in the industries followed by the cascade control strategy. Advanced control strategies like multivariable control, model-based control, and adaptive control find limited industrial applications thus far. Despite major advancements that have been accomplished in the last two decades, more needs to be done to gain wider acceptance amongst manufacturers. The simultaneous use of 'all' available process information, its processing and convergence to meaningful action is a complex task and requires expertise. However, by integrating accessible process information at different levels of sophistication advance control schemes can be implemented. Based on the process understanding, advanced bioprocess control can be successfully applied (Figure 4) by integrating expert systems and artificial intelligence. Organized use of schematic information and logical process description gained by experience is key to success [107,109-111]. Understanding the relationship between the CQA (process outputs) and the CPP (measurable process operational variables) is essential for creating an effective control scheme [133], and performing real-time monitoring [134-136], as well as fault diagnosis [137].

In recent times, PAT based methodologies have encouraged biopharmaceutical industries to change their modus operandi from quality by inspection to quality by design (QbD). However, the reluctance in industrial adoption is mainly due to the complex regulatory environment and issues faced in implementation of technology [138]. Additionally, for bioprocesses, high level of process understanding and control is required. Lately, spectroscopic PAT tools are gaining importance due to their ability to non-intrusively measure multiple process variables in real time. Additionally, spectroscopic tools can be used to screen cell culture media that helps in identifying correlations between the CPP and CQA's [139]. The generated data can be processed via multivariate data analysis (MVDA). Figure 5 depicts an example of advanced monitoring of CPPs for a bioreactor, the data from which can be analysed and used for facilitating advanced process control. 

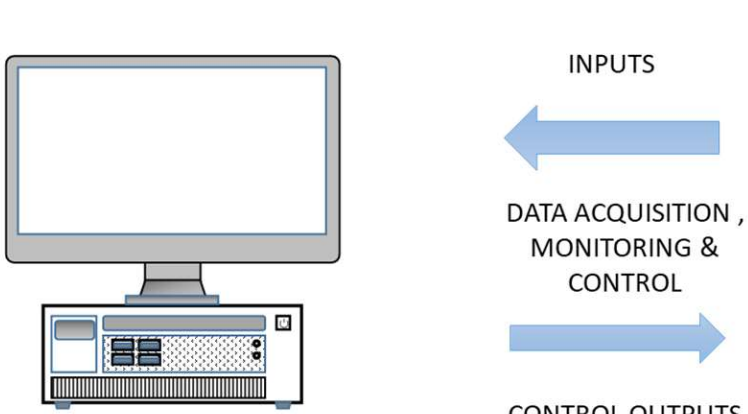

Bioprocess (simplified)

CONTROL OUTPUTS

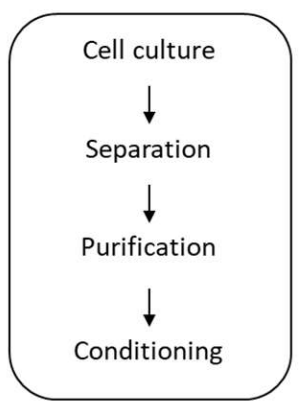

PAT Platform Implementation

\section{QbD Methodology \\ $\triangleright$ Critical Process Parameters \\ $\triangleright$ Critical Quality Attributes}

\section{Process Operation}

$\triangleright$ Characterization

$\triangleright$ Optimization
Process Outcome

$>$ High Productivity

$>$ Desired Product Quality

$>$ Reproducibility

Figure 4. Bioprocess control implementation in the Quality by Design (QbD) paradigm.

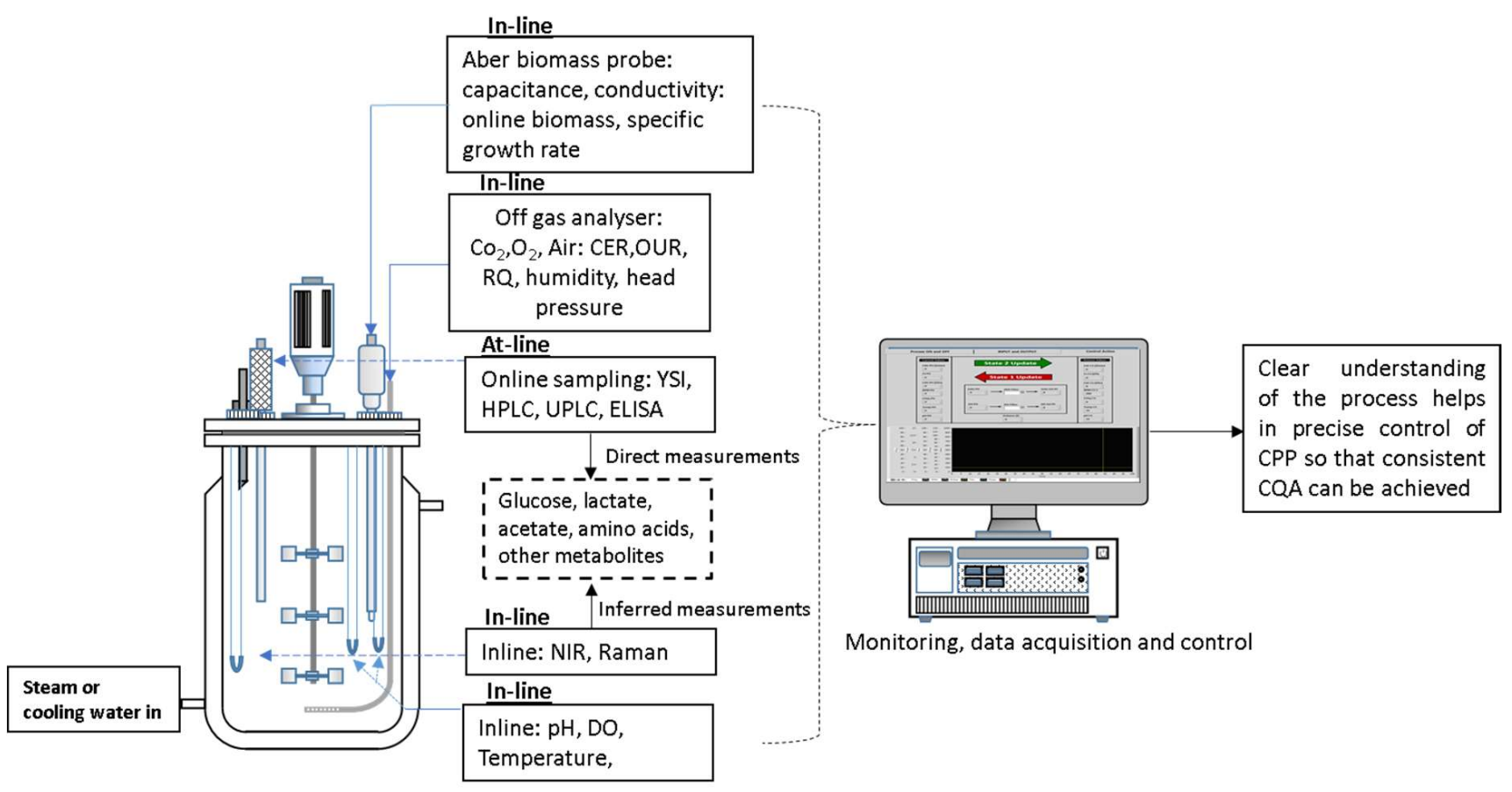

Figure 5. Example of advances in process monitoring for measurement of critical process parameter in bioreactor.

\subsection{Automation in Biomanufacturing}

Onset of automation in biomanufacturing is a key step towards robust process control (Figure 6). Digitalization is the new mantra with online sensors spewing continuous data on a multitude of variables [140]. Developments of inline and at-line sensors, wireless technology for connectivity of sensors to servers, smart sensors for acquiring data, and advancements in sensor calibration and compact technology are being increasingly used to address space limitations and logistic constraints. However, open platform communications or object linking and embedding approach can be implemented for integrating unit operations $[141,142]$. A key challenge that remains is that of incorporation of the auto- 
mated and isolated workstation into the continuous workflow without affecting process efficiency. This includes consistency between different versions of the software, proprietary interfaces, and various data formats. Therefore, the primary need for successful integration is the use of standardized communication protocols and graphical user interfaces [136]. A critical criterion in the acceptance of middleware among users is scalability and flexibility. Integration of enterprise control system (ECS) into business systems (BS), manufacturing execution systems (MES), and shop-floor control systems (SFC) is the next stage of primary challenge to tackle when implementing a plant-wide information control system. Progress in integration-in-manufacturing through centralized/distributed hardware/software automation architectures is continuously growing via intelligence-in-manufacturing epitome addressed by industry centric $\mathrm{R} \& \mathrm{D}$ activities. As an example, supervisory control and data acquisition (SCADA) platform is implemented for an end-to-end integrated process wherein the system integrates and analyses different unit operations and collects and stores data to enable monitoring and control [143]. Additionally, the concept of digital twin for enabling control is shown for small scale end-to-end monoclonal antibody production platform [105]. However, full potential of automation in end-to-end bio-manufacturing process at industrial scale is yet to be realized.

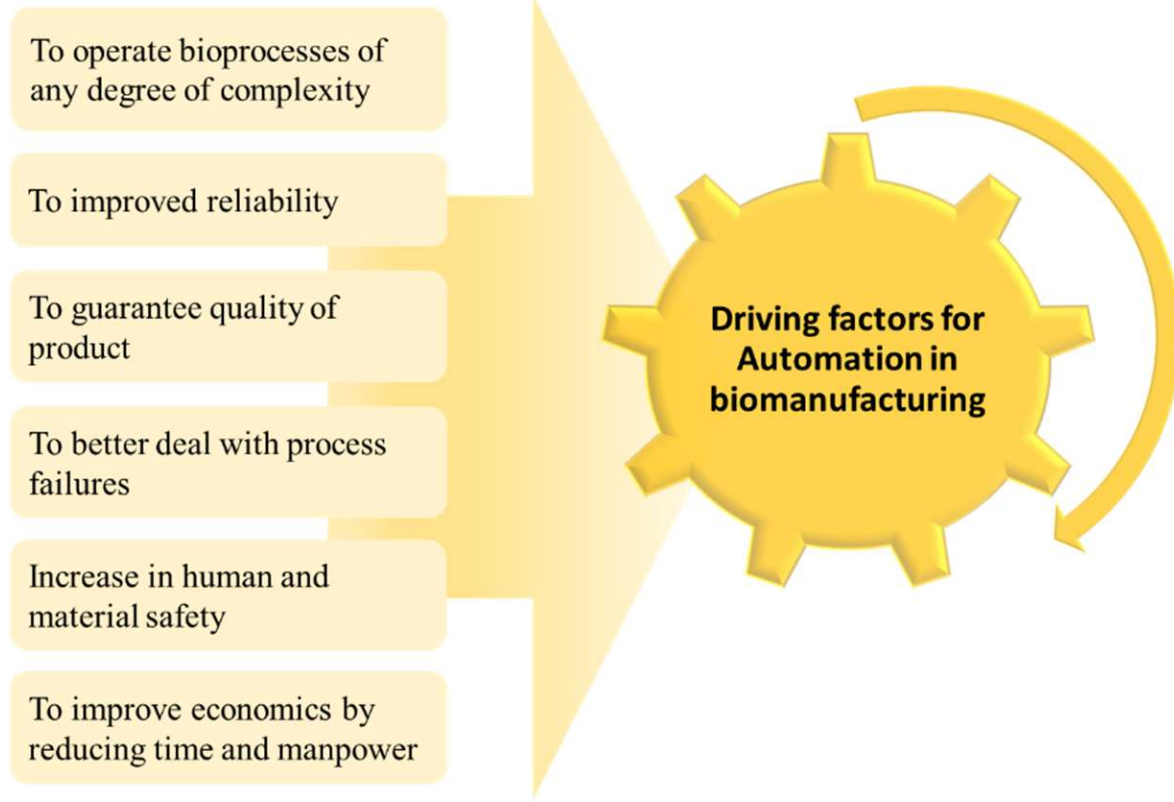

Figure 6. Benefits of automation in a biomanufacturing process.

Another significant challenge revolves around data analysis. Bioprocess analytics is recognized as a crucial technical barrier to the acceptance of bio-manufacturing automation. Research labs are producing an increasing amount of data, both in quantity and complexity, which requires further analysis $[144,145]$. Further, the regulatory agencies are focused on issues around data integrity [144]. Therefore, operable and industry standard software systems are needed for data management. In addition, bio-manufacturing systems must be designed such that they can handle the high complexity of the data and have sufficient agility and flexibility.

\section{Conclusions}

In the last two decades, tremendous enhancement in process productivity has been realized. Advancements in process control and monitoring have helped in reducing development costs and improving affordability. Considering the associated complexity and inconsistency, manufacturing of products like $\mathrm{mAbs}$ poses a major challenge to conventional production practices. Inspired by the recent regulatory guidelines within the $\mathrm{QbD}$ 
framework, stochastic and mechanistic model-based controllers are now emerging as popular choices for bioprocess control. Contrary to the traditional experimental approach, it is observed that the utilization of simulations and advanced statistics results in a low cost and in a shorter time. This has led to the development of process control strategies, from cascade to adaptive to hybrid, along with introduction of neural network (NN)-based controllers. Recent efforts have been made to conceptualize holistic process model-based controllers that offer a digital replica of the end-to-end bioprocess. It involves integration of individual unit operation along with monitoring and control, providing deeper insight on the impact of complex correlations between CPPs and CQAs for coupled unit operations. At present, model-based controllers are capable of contributing towards root cause analysis, molecular interactions, and refinement of unit operation models. However, they typically have high computational burden. In recent times, neural network-based control strategies have made significant progress, but their use in process modelling requires extensive datasets. Hence, an integrated approach combining statistical models with detailed theoretical models is required to avoid comprehensive experimentation and obtain deeper understanding. Thus, control strategies need to be designed aiming to achieve high levels of precision, accuracy, and robustness.

In addition, automation in manufacturing would provide substantial opportunities to overcome many of the challenges faced in commercial success. However, major technical and business strategy challenges are encountered while creating scalable and automated bio-manufacturing solutions. Thus, biotherapeutic developers must think from the perspective of large-scale production and should incorporate automation concepts from the earliest stage of process development. Inadequacy of standardization across software, hardware and design specification complicates the attempts of automation. To overcome these barriers, manufacturers must continue to increase their process understanding and utilize this understanding to develop a streamlined and efficient bio-manufacturing process featuring validated in-process testing and control. Last but not the least, stakeholders and technical solution providers should attempt to meet the innovation gap in biomanufacturing and liaise jointly with biotherapeutic developers to design and develop automated solutions.

Author Contributions: S.N., S.M. and P.P. wrote the first draft of the manuscript. A.S.R. conceptualized the manuscript, received the funding, supervised the project, and reviewed and edited the manuscript. All authors have read and agreed to the published version of the manuscript.

Funding: This work was funded by the Department of Biotechnology, Ministry of Science and Technology (number BT/COE/34/SP15097/2015) and by Biotechnology Industry Research Assistance Council (number BT/NBM0159/04/2019).

Institutional Review Board Statement: Not applicable.

Informed Consent Statement: Not applicable.

Data Availability Statement: Not applicable.

Conflicts of Interest: The authors declare no conflict of interest.

\section{References}

1. Alford, J.S. Bioprocess control: Advances and challenges. Comput. Chem. Eng. 2006, 30, 1464-1475. [CrossRef]

2. Available online: https://www.nature.com/articles/d43747-020-00765-2\#: :text=From\%20the\%20publishers\%20of\%20Nature, attract $\% 20$ partners\%20and\%20dealmaking\%20opportunities (accessed on 11 February 2021).

3. Available online: https://www.alliedmarketresearch.com/biopharmaceutical-market (accessed on 11 February 2021).

4. Zulkeflee, S.A.; Aziz, N. Control Implementation in Bioprocess System: A Review. In Proceedings of the International Conference on Control, Instrumentation and Mechatronics Engineering (CIM'07), Johor Bahru, Malaysia, 28-29 May 2007; pp. 798-804.

5. Hong, M.S.; Severson, K.A.; Jiang, M.; Lu, A.E.; Love, J.C.; Braatz, R.D. Challenges and opportunities in biopharmaceutical manufacturing control. Comput. Chem. Eng. 2018, 110, 106-114. [CrossRef]

6. Baishan, F.; Hongwen, C.; Xiaolan, X.; Ning, W.; Zongding, H. Using genetic algorithms coupling neural networks in a study of xylitol production: Medium optimisation. Process. Biochem. 2003, 38, 979-985. [CrossRef]

7. Franco-Lara, E.; Link, H.; Weuster-Botz, D. Evaluation of artificial neural networks for modelling and optimization of medium composition with a genetic algorithm. Process. Biochem. 2006, 41, 2200-2206. [CrossRef] 
8. Jenzsch, M.; Gnoth, S.; Beck, M.; Kleinschmidt, M.; Simutis, R.; Lübbert, A. Open-loop control of the biomass concentration within the growth phase of recombinant protein production processes. J. Biotechnol. 2006, 127, 84-94. [CrossRef]

9. Jenzsch, M.; Gnoth, S.; Kleinschmidt, M.; Simutis, R.; Lübbert, A. Improving the batch-to-batch reproducibility in microbial cultures during recombinant protein production by guiding the process along a predefined total biomass profile. Bioprocess. Biosyst. Eng. 2006, 29, 315-321. [CrossRef]

10. Gronemeyer, P.; Ditz, R.; Strube, J. Trends in upstream and downstream process development for antibody manufacturing. Bioengineering 2014, 1, 188-212. [CrossRef] [PubMed]

11. Rathore, A.S.; Sofer, G. Process Validation in Manufacturing of Biopharmaceuticals. In Biotechnology and Bioprocessing; CRC Press: Boca Raton, FL, USA, 2012.

12. Parenteral drug Association. PDA technical report no. 42: Process validation of protein manufacturing. PDA J. Pharm. Sci. Technol. 2005, 59 (Suppl. S4), 1-28.

13. Conor, M.; Qi, Z.; Prodromos, D.; Wei-Shou, H. A hybrid mechanistic-empirical model for in silico mammalian cell bioprocess simulation. Metab. Eng. 2021, 66, 31-40.

14. Oliver, J.F.; Nicholas, J.W.; Laura, P.; Darren, B.; Martin, R.; Rachel, L.G. Multiple target data-driven models to enable sustainable process manufacturing: An industrial bioprocess case study. J. Clean. Prod. 2021, 296, 126242.

15. Hong, M.S.; Braatz, R.D. Mechanistic modeling and parameter-adaptive nonlinear model predictive control of a microbioreactor. Comput. Chem. Eng. 2021, 147, 107255. [CrossRef]

16. Frank, N.; Alexandre, T.; Klaus-Robert, M.; Cecilia, C. Machine Learning for Molecular Simulation. Annu. Rev. Phys. Chem. 2020, 71,361-390.

17. Sebastian, R.; Benjamin, K. Machine learning and AI-based approaches for bioactive ligand discovery and GPCR-ligand recognition. Methods 2020, 180, 89-110.

18. Gupta, R.; Srivastava, D.; Sahu, M.; Tiwari, S.; Ambasta, R.K.; Kumar, P. Artificial intelligence to deep learning: Machine intelligence approach for drug discovery. Mol. Divers. 2021, 1-46. [CrossRef]

19. Rathore, A.S.; Winkle, H. Quality by design for biopharmaceuticals: Regulatory perspective and approach. Nat. Biotechnol. 2009, 27, 26-34. [CrossRef]

20. Rathore, A.S.; Bhambure, R.; Ghare, V. Process analytical technology (PAT) for biopharmaceutical products. Anal. Bioanal. Chem. 2010, 398, 137-154. [CrossRef]

21. Rathore, A.S. Roadmap for implementation of quality by design (QbD) for biotechnology products. Trends Biotechnol. 2009, 27, 546-553. [CrossRef] [PubMed]

22. U.S. Department of Health and Human Services, Food and Drug Administration. Guidance for Industry: PAT-A Framework for Innovative Pharmaceutical Development, Manufacturing Andquality Assurance. 2004. Available online: http://www.fda.gov / downloads/Drugs/GuidanceComplianceRegulatoryInformation/Guidances/ucm070305.pdf (accessed on 11 February 2021).

23. Rathore, A.S. QbD/PAT for bioprocessing: Moving from theory to implementation. Curr. Opin. Chem. Eng. 2014, 6, 1-8. [CrossRef]

24. Ögmundarson, Ó.; Sukumara, S.; Herrgård, M.J.; Fantke, P. Combining environmental and economic performance for bioprocess optimization. Trends Biotechnol. 2020, 38, 1203-1214. [CrossRef]

25. Narayanan, H.; Luna, M.F.; Von Stosch, M.; Bournazou, M.N.C.; Polotti, G.; Morbidelli, M.; Butté, A.; Sokolov, M. Bioprocessing in the digital age: The role of process models. Biotechnol. J. 2020, 15, e1900172. [CrossRef] [PubMed]

26. Bunnak, P.; Allmendinger, R.; Ramasamy, S.V.; Lettieri, P.; Titchener-Hooker, N.J. Life-cycle and cost of goods assessment of fed-batch and perfusion-based manufacturing processes for mAbs. Biotechnol. Prog. 2016, 32, 1324-1335. [CrossRef]

27. Farid, S.S.; Baron, M.; Stamatis, C.; Nie, W.; Coffman, J. Benchmarking biopharmaceutical process development and manufacturing cost contributions to R\&D. mAbs 2020, 12, 1754999. [CrossRef] [PubMed]

28. Zürcher, P.; Shirahata, H.; Badr, S.; Sugiyama, H. Multi-stage and multi-objective decision-support tool for biopharmaceutical drug product manufacturing: Equipment technology evaluation. Chem. Eng. Res. Des. 2020, 161, 240-252. [CrossRef]

29. Ramasamy, S.V.; Titchener-Hooker, N.J.; Lettieri, P. Life cycle assessment as a tool to support decision making in the biopharmaceutical industry: Considerations and challenges. Food Bioprod. Process. 2015, 94, 297-305. [CrossRef]

30. Mears, L.; Stocks, S.M.; Albaek, M.O.; Sin, G.; Gernaey, K.V. Mechanistic fermentation models for process design, monitoring, and control. Trends Biotechnol. 2017, 35, 914-924. [CrossRef]

31. Yee, J.C.; Rehmann, M.S.; Yao, G.; Sowa, S.W.; Aron, K.L.; Tian, J.; Borys, M.C.; Li, Z.J. Advances in process control strategies for mammalian fed-batch cultures. Curr. Opin. Chem. Eng. 2018, 22, 34-41. [CrossRef]

32. Mears, L.; Stocks, S.M.; Sin, G.; Gernaey, K.V. A review of control strategies for manipulating the feed rate in fed-batch fermentation processes. J. Biotechnol. 2017, 245, 34-46. [CrossRef] [PubMed]

33. Liu, W.-C.; Inwood, S.; Gong, T.; Sharma, A.; Yu, L.-Y.; Zhu, P. Fed-batch high-cell-density fermentation strategies for Pichia pastoris growth and production. Crit. Rev. Biotechnol. 2019, 39, 258-271. [CrossRef]

34. Julia, R.; Xavier, G.; José, L.M.; Denise, F.; Francisco, V. Continuous operation, a realistic alternative to fed-batch fermentation for the production of recombinant lipase B from Candida antarctica under the constitutive promoter PGK in Pichia pastoris. Biochem. Eng. J. 2019, 147, 39-47.

35. Khan, O.; Madhuranthakam, C.M.R.; Douglas, P.; Lau, H.; Sun, J.; Farrell, P. Optimized PID controller for an industrial biological fermentation process. J. Process. Control. 2018, 71, 75-89. [CrossRef] 
36. De Freitas, H.F.S.; Olivo, J.E.; Andrade, C.M.G. Optimization of bioethanol in silico production process in a fed-batch bioreactor using non-linear model predictive control and evolutionary computation techniques. Energies 2017, 10, 1763. [CrossRef]

37. García, C.; Alcaraz, W.; Acosta-Cárdenas, A.; Ochoa, S. Application of process system engineering tools to the fed-batch production of poly(3-hydroxybutyrate-co-3-hydroxyvalerate) from a vinasses-molasses Mixture. Bioprocess. Biosyst. Eng. 2019, 42, 1023-1037. [CrossRef]

38. Scomparin, A.; Bureik, M. A convenient new method for reproducible fed-batch fermentation of fission yeast Schizosaccharomyces pombe. Biotechnol. Lett. 2020, 42, 937-943. [CrossRef]

39. Pantano, M.N.; Serrano, M.E.; Fernández, M.C.; Rossomando, F.G.; Ortiz, O.A.; Scaglia, G.J.E. Multivariable control for tracking optimal profiles in a nonlinear fed-batch bioprocess integrated with state estimation. Ind. Eng. Chem. Res. 2017, 56, 6043-6056. [CrossRef]

40. Joanofarc, X.; Nivedhika, D.; Patnaik, S.; Panda, R. Closed-loop Performance and Analysis of a Real Time Non-linear Bioreactor Process. In Proceedings of the 2019 2nd International Conference on Power and Embedded Drive Control (ICPEDC), Chennai, India, 21-23 August 2019; Institute of Electrical and Electronics Engineers (IEEE): Piscataway, NJ, USA, 2019 ; pp. $406-412$.

41. Kumar, M.; Prasad, D.; Giri, B.S.; Singh, R.S. Temperature control of fermentation bioreactor for ethanol production using IMC-PID controller. Biotechnol. Rep. 2019, 22, e00319. [CrossRef]

42. Abadli, M.; Dewasme, L.; Tebbani, S.; Dumur, D.; Wouwer, A.V. Generic Model Control Applied to E. coli BL21(DE3) Fed-Batch Cultures. Process 2020, 8, 772. [CrossRef]

43. Carredano, E.N.; Nordberg, R.; Westin, S.; Busson, K.; Karlsson, T.M.; Blank, T.S.; Sandegren, H.; Jagschies, G. Simplification of Buffer formulation and improvement of buffer control with in-line conditioning (IC). Biopharm. Process. 2018, 513-525. [CrossRef]

44. Fabbrini, D.; Simonini, C.; Lundkvist, J.; Carredano, E.; Otero, D. Addressing the challenge of complex buffer management an in-line conditioning collaboration. BioProcess Int. 2017, 15, 43-46.

45. Sendrescu, D.; Petre, E.; Selisteanu, D. Nonlinear PID controller for a Bacterial Growth Bioprocess. In Proceedings of the 2017 18th International Carpathian Control Conference (ICCC), Sinaia, Romania, 28-31 May 2017; Institute of Electrical and Electronics Engineers (IEEE): Piscataway, NJ, USA, 2017; pp. 151-155.

46. Simutis, R.; Lübbert, A. Bioreactor control improves bioprocess performance. Biotechnol. J. 2015, 10, 1115-1130. [CrossRef] [PubMed]

47. Schlembach, I.; Grünberger, A.; Rosenbaum, M.A.; Regestein, L. Measurement techniques to resolve and control population dynamics of mixed-culture processes. Trends Biotechnol. 2021. [CrossRef] [PubMed]

48. Kager, J.; Tuveri, A.; Ulonska, S.; Kroll, P.; Herwig, C. Experimental verification and comparison of model predictive, PID and model inversion control in a Penicillium chrysogenum fed-batch process. Process. Biochem. 2020, 90, 1-11. [CrossRef]

49. Bolton, W. Controllers. In Instrumentation and Control Systems, 3rd ed.; Elsevier Science: Amsterdam, The Netherlands, 2021; pp. 297-327, Chapter 13.

50. Raja, G.L.; Ali, A. Modified parallel cascade control structure for integrating processes. In Proceedings of the 2015 International Conference on Recent Developments in Control, Automation and Power Engineering (RDCAPE), Noida, India, 12-13 March 2015; Institute of Electrical and Electronics Engineers (IEEE): Piscataway, NJ, USA, 2015; pp. 90-95.

51. Campos-Rodríguez, A.; García-Sandoval, J.; González-Álvarez, V. Hybrid cascade control for a class of nonlinear dynamical systems. J. Process. Control. 2019, 76, 141-154. [CrossRef]

52. Raja, G.L.; Ali, A. Series cascade control: An outline survey. In Proceedings of the 2017 Indian Control Conference (ICC), Guwahati, India, 4-6 January 2017; Institute of Electrical and Electronics Engineers (IEEE): Piscataway, NJ, USA, 2017; pp. 409-414.

53. Velez-Suberbie, M.L.; Betts, J.P.J.; Walker, K.L.; Robinson, C.; Zoro, B.; Keshavarz-Moore, E. High throughput automated microbial bioreactor system used for clone selection and rapid scale-down process optimization. Biotechnol. Prog. 2018, 34, 58-68. [CrossRef]

54. Hoshan, L.; Jiang, R.; Moroney, J.; Bui, A.; Zhang, X.; Hang, T.-C.; Xu, S. Effective bioreactor pH control using only sparging gases. Biotechnol. Prog. 2019, 35, e2743. [CrossRef] [PubMed]

55. Gehan, O.; Pigeon, E.; Menard, T.; Mosrati, R.; Pouliquen, M.; Fall, L.; Reuter, J. Dissolved oxygen level output feedback control based on discrete-time measurements during a Pseudomonas putida mt-2 fermentation. J. Process. Control. 2019, 79, 29-40. [CrossRef]

56. Kuprijanov, A.; Schaepe, S.; Aehle, M.; Simutis, R.; Lübbert, A. Improving cultivation processes for recombinant protein production. Bioprocess. Biosyst. Eng. 2011, 35, 333-340. [CrossRef]

57. Sommeregger, W.; Sissolak, B.; Kandra, K.; Von Stosch, M.; Mayer, M.; Striedner, G. Quality by control: Towards model predictive control of mammalian cell culture bioprocesses. Biotechnol. J. 2017, 12. [CrossRef]

58. Sansana, J.; Joswiak, M.N.; Castillo, I.; Wang, Z.; Rendall, R.; Chiang, L.H.; Reis, M.S. Recent trends on hybrid modeling for Industry 4.0. Comput. Chem. Eng. 2021, 2021, 107365. [CrossRef]

59. Hille, R.; Brandt, H.; Colditz, V.; Classen, J.; Hebing, L.; Langer, M.; Kreye, S.; Neymann, T.; Krämer, S.; Tränkle, J.; et al. Application of model-based online monitoring and robust optimizing control to fed-batch bioprocesses. IFAC-PapersOnLine 2020, 53, 16846-16851. [CrossRef]

60. Sha, S.; Huang, Z.; Wang, Z.; Yoon, S. Mechanistic modeling and applications for CHO cell culture development and production. Curr. Opin. Chem. Eng. 2018, 22, 54-61. [CrossRef] 
61. Jabarivelisdeh, B.; Carius, L.; Findeisen, R.; Waldherr, S. Adaptive predictive control of bioprocesses with constraint-based modeling and estimation. Comput. Chem. Eng. 2020, 135, 106744. [CrossRef]

62. Sridhar, L.N. Multiobjective optimization and nonlinear model predictive control of the continuous fermentation process involving Saccharomyces Cerevisiae. Biofuels 2019, 1, 1-16. [CrossRef]

63. Chang, L.; Liu, X.; Henson, M.A. Nonlinear model predictive control of fed-batch fermentations using dynamic flux balance models. J. Process. Control. 2016, 42, 137-149. [CrossRef]

64. Santos, L.; Dewasme, L.; Coutinho, D.; Wouwer, A.V. Nonlinear model predictive control of fed-batch cultures of micro-organisms exhibiting overflow metabolism: Assessment and robustness. Comput. Chem. Eng. 2012, 39, 143-151. [CrossRef]

65. Gorrini, F.; Biagiola, S.; Figueroa, J.L.; Wouwer, A.V. Reaction rate estimation and model predictive control of hybridoma cell cultures. IFAC-PapersOnLine 2019, 52, 715-720. [CrossRef]

66. Dewasme, L.; Fernandes, S.; Amribt, Z.; Santos, L.; Bogaerts, P.; Wouwer, A.V. State estimation and predictive control of fed-batch cultures of hybridoma cells. J. Process. Control. 2015, 30, 50-57. [CrossRef]

67. Lyon, D. Achieving active control of cell culture performance with the aid of machine learning techniques, Abstracts. In Proceedings of the 74th Northwest Regional Meeting of the American Chemical Society, NORM-298. Portland, OR, USA, 16-19 June 2019.

68. Papathanasiou, M.M.; Burnak, B.; Katz, J.; Shah, N.; Pistikopoulos, E.N. Assisting continuous biomanufacturing through advanced control in downstream purification. Comput. Chem. Eng. 2019, 125, 232-248. [CrossRef]

69. Noll, P.; Henkel, M. History and evolution of modeling in biotechnology: Modeling \& simulation, application and hardware performance. Comput. Struct. Biotechnol. J. 2020, 18, 3309-3323. [CrossRef]

70. Lauri, D.; Lennox, B.; Camacho, J. Model predictive control for batch processes: Ensuring validity of predictions. J. Process. Control. 2014, 24, 239-249. [CrossRef]

71. Kotidis, P.; Demis, P.; Goey, C.H.; Correa, E.; McIntosh, C.; Trepekli, S.; Shah, N.; Klymenko, O.V.; Kontoravdi, C. Constrained global sensitivity analysis for bioprocess design space identification. Comput. Chem. Eng. 2019, 125, 558-568. [CrossRef]

72. Armstrong, A.; Horry, K.; Cui, T.; Hulley, M.; Turner, R.; Farid, S.S.; Goldrick, S.; Bracewell, D.G. Advanced control strategies for bioprocess chromatography: Challenges and opportunities for intensified processes and next generation products. J. Chromatogr. A 2021, 1639, 461914. [CrossRef]

73. Abiodun, O.I.; Jantan, A.; Omolara, A.E.; Dada, K.V.; Mohamed, N.A.; Arshad, H. State-of-the-art in artificial neural network applications: A survey. Heliyon 2018, 4, e00938. [CrossRef] [PubMed]

74. Del Rio-Chanona, E.A.; Manirafasha, E.; Zhang, D.; Yue, Q.; Jing, K. Dynamic modeling and optimization of cyanobacterial C-phycocyanin production process by artificial neural network. Algal Res. 2016, 13, 7-15. [CrossRef]

75. Natarajan, P.; Moghadam, R.; Jagannathan, S. Online deep neural network-based feedback control of a Lutein bioprocess. J. Process. Control. 2021, 98, 41-51. [CrossRef]

76. Rómoli, S.; Serrano, M.; Rossomando, F.; Vega, J.; Ortiz, O.; Scaglia, G. Neural network-based state estimation for a closed-loop control strategy applied to a fed-batch bioreactor. Complex 2017, 2017, 9391879. [CrossRef]

77. Murugan, C.; Natarajan, P. Estimation of fungal biomass using multiphase artificial neural network based dynamic soft sensor. J. Microbiol. Methods 2019, 159, 5-11. [CrossRef] [PubMed]

78. López, M.E.; Rene, E.R.; Boger, Z.; Veiga, M.C.; Kennes, C. Modelling the removal of volatile pollutants under transient conditions in a two-stage bioreactor using artificial neural networks. J. Hazard. Mater. 2017, 324, 100-109. [CrossRef] [PubMed]

79. Sena, H.J.; da Silva, F.V.; Fileti, A.M.F. ANN model adaptation algorithm based on extended Kalman filter applied to pH control using MPC. J. Process. Control. 2021, 102, 15-23. [CrossRef]

80. Tavasoli, T.; Arjmand, S.; Siadat, S.O.R.; Shojaosadati, S.A.; Lotfi, A.S. A robust feeding control strategy adjusted and optimized by a neural network for enhancing of alpha 1-antitrypsin production in Pichia pastoris. Biochem. Eng. J. 2019, 144, 18-27. [CrossRef]

81. Kahraman, C.; Öztayşi, B.; Onar, S.; Çevik, A. Comprehensive Literature Review of 50 Years of Fuzzy Set Theory. Int. J. Comput. Intell. Syst. 2016, 9, 3-24. [CrossRef]

82. Abyad, M.; Karama, A.; Khallouq, A. Fuzzy Takagi-Sugeno based modelling and control for an alcoholic fermentation process. In Proceedings of the 2017 International Conference on Electrical and Information Technologies (ICEIT), Rabat, Morocco, 15-18 November 2017; Institute of Electrical and Electronics Engineers (IEEE): Piscataway, NJ, USA, 2017; pp. 1-6.

83. Abyad, M.; Karama, A.; Khallouq, A. Takagi-Sugeno tracking control of a fermentation process with respect to asymmetric constraints. Int. J. Adapt. Control. Signal. Process. 2019, 34, 266-282. [CrossRef]

84. Khamparia, A.; Pandey, B.; Pandey, D.; Gupta, D.; Khanna, A.; de Albuquerque, V.H.C. Comparison of RSM, ANN and fuzzy logic for extraction of oleonolic acid from ocimum sanctum. Comput. Ind. 2020, 117, 103200. [CrossRef]

85. Fonseca, R.R.; Franco, I.C.; Da Silva, F.V. Bioreactor temperature control using a generic fuzzy feedforward control system. In Proceedings of the 15th IASTED International Conference Intelligent Systems and Control (ISC 2016), Campinas, Brazil, 16-18 August 2016. [CrossRef]

86. Fonseca, R.R.; Sencio, R.R.; Franco, I.C.; Da Silva, F.V. An adaptive fuzzy feedforward-feedback control system applied to a saccharification process. Chem. Prod. Process. Model. 2018, 13, 13. [CrossRef]

87. Escalante-Sánchez, A.; Barrera-Cortés, J.; Poggi-Varaldo, H.M.; Ponce-Noyola, T.; Baruch, I.S. A soft sensor based on online biomass measurements for the glucose estimation and control of fed-batch cultures of Bacillus thuringiensis. Bioprocess Biosyst. Eng. 2018, 41, 1471-1484. [CrossRef] 
88. Humbird, D.; Fei, Q. Scale-Up Considerations for Biofuels. In Biotechnology for Biofuel Production and Optimization; Eckert, C.A., Trinh, C.T., Eds.; Elsevier: Amsterdam, The Netherlands, 2016; pp. 513-537.

89. Benattia, S.E.; Tebbani, S.; Dumur, D. Linearized min-max robust model predictive control: Application to the control of a bioprocess. Int. J. Robust Nonlinear Control. 2020, 30, 100-120. [CrossRef]

90. Pistikopoulos, E.N.; Diangelakis, N.A.; Oberdieck, R.; Papathanasiou, M.M.; Nascu, I.; Sun, M. PAROC-An integrated framework and software platform for the optimisation and advanced model-based control of process systems. Chem. Eng. Sci. 2015, 136, 115-138. [CrossRef]

91. Papathanasiou, M.M.; Avraamidou, S.; Oberdieck, R.; Mantalaris, A.; Steinebach, F.; Morbidelli, M.; Mueller-Spaeth, T.; Pistikopoulos, S. Advanced control strategies for the multicolumn countercurrent solvent gradient purification process. AIChE J. 2016, 62, 2341-2357. [CrossRef]

92. Papathanasiou, M.M.; Burnak, B.; Katz, J.; Shah, N.; Pistikopoulos, S. Control of a dual mode separation process via multiparametric Model Predictive Control. IFAC-PapersOnLine 2019, 52, 988-993. [CrossRef]

93. Papathanasiou, M.M.; Burnak, B.; Katz, J.; Müller-Späth, T.; Morbidelli, M.; Shah, N.; Pistikopoulos, E.N. Control of small-scale chromatographic systems under disturbances. In Computer Aided Chemical Engineering; Salvador Garcia Muñoz, S.G., Laird, C.D., Realff, M.J., Eds.; Elsevier: Amsterdam, The Netherlands, 2019; Volume 47, pp. 269-274.

94. Papathanasiou, M.M.; Steinebach, F.; Morbidelli, M.; Mantalaris, A.; Pistikopoulos, E.N. Intelligent, model-based control towards the intensification of downstream processes. Comput. Chem. Eng. 2017, 105, 173-184. [CrossRef]

95. Steinebach, F.; Angarita, M.; Karst, D.J.; Müller-Späth, T.; Morbidelli, M. Model based adaptive control of a continuous capture process for monoclonal antibodies production. J. Chromatogr. A 2016, 1444, 50-56. [CrossRef]

96. Lim, H.-K.; Choi, S.-J.; Kim, K.-Y.; Jung, K.-H. Dissolved-oxygen-stat controlling two variables for methanol induction of rGuamerin in Pichia pastoris and its application to repeated fed-batch. Appl. Microbiol. Biotechnol. 2003, 62, 342-348. [CrossRef]

97. Potvin, G.; Ahmad, A.; Zhang, Z. Bioprocess engineering aspects of heterologous protein production in Pichia pastoris: A review. Biochem. Eng. J. 2012, 64, 91-105. [CrossRef]

98. Zheng, R.; Pan, F. On-Line Tendency Control of Dissolved Oxygen Concentration during Aerobic Fed-Batch Fermentations. Appl. Sci. 2019, 9, 5232. [CrossRef]

99. Ding, J.; Gao, M.J.; Hou, G.L.; Liang, K.X.; Yu, R.S.; Li, Z.; Shi, Z.P. Stabilizing porcine interferon- $\alpha$ production by Pichia pastoris with an ethanol on-line measurement based DO-Stat glycerol feeding strategy. J. Chem. Technol. Biotechnol. 2015, 89, 1948-1953. [CrossRef]

100. García-Arrazola, R.; Siu, S.C.; Chan, G.; Buchanan, I.; Doyle, B.; Titchener-Hooker, N.; Baganz, F. Evaluation of a pH-stat feeding strategy on the production and recovery of Fab' fragments from E. coli. Biochem. Eng. J. 2005, 23, 221-230. [CrossRef]

101. Li, K.-T.; Liu, D.-H.; Chu, J.; Wang, Y.-H.; Zhuang, Y.-P.; Zhang, S.-L. An effective and simplified pH-stat control strategy for the industrial fermentation of vitamin B12 by Pseudomonas denitrificans. Bioprocess. Biosyst. Eng. 2008, 31, 605-610. [CrossRef]

102. Bastin, G.; Nešić, D.; Tan, Y.; Mareels, I. On extremum seeking in bioprocesses with multivalued cost functions. Biotechnol. Prog. 2009, 25, 683-689. [CrossRef] [PubMed]

103. Daaou, B.; Dochain, D.; Bachir, D. High order sliding mode observer based extremum seeking controller for a continuous stirred tank bioreactor. In Proceedings of the 2015 3rd International Conference on Control, Engineering \& Information Technology (CEIT), Tlemcen, Algeria, 25-27 May 2015; Institute of Electrical and Electronics Engineers (IEEE): Piscataway, NJ, USA, 2015; pp. $1-6$.

104. Johnsson, O.; Sahlin, D.; Linde, J.; Lidén, G.; Hägglund, T. A mid-ranging control strategy for non-stationary processes and its application to dissolved oxygen control in a bioprocess. Control. Eng. Pr. 2015, 42, 89-94. [CrossRef]

105. Gomis-Fons, J.; Schwarz, H.; Zhang, L.; Andersson, N.; Nilsson, B.; Castan, A.; Solbrand, A.; Stevenson, J.; Chotteau, V. Modelbased design and control of a small-scale integrated continuous end-to-end mAb platform. Biotechnol. Prog. 2020, 36, e2995. [CrossRef]

106. Jiang, M.; Braatz, R.D. Integrated control of continuous (bio)pharmaceutical manufacturing. Am. Pharm Rev. 2016, 19, 110-115.

107. Birle, S.; Hussein, M.A.; Becker, T. Management of Uncertainty by Statistical Process Control and a Genetic Tuned Fuzzy System. Discret. Dyn. Nat. Soc. 2016, 2016, 1-11. [CrossRef]

108. Bose, B.K. Artificial intelligence applications in renewable energy systems and smart grid-Some novel applications. In Power Electronics in Renewable Energy Systems and Smart Grid; Wiley: Hoboken, NJ, USA, 2019; pp. 625-675.

109. Precup, R.-E.; David, R.-C. Nature-inspired algorithms for the optimal tuning of fuzzy controllers. In Nature-inspired Optimization Algorithms for Fuzzy Controlled Servo Systems; Elsevier: Amsterdam, The Netherlands, 2019; pp. 55-80.

110. Rios, J.D.; Alanis, A.Y.; Arana-Daniel, N.; Lopez-Franco, C. Neural Networks Modeling and Control. In Neural Networks Modeling and Control; Elsevier BV: Amsterdam, The Netherlands, 2020.

111. Ahmad, S.K.; Guenard, R.; Romero-Torres, S.; Antoniou, C. Hybrid model identification for monoclonal antibody production bioreactor-A digital twin. Am. Pharm Rev. 2019, 22, 1-12.

112. Randek, J.; Mandenius, C.-F. On-line soft sensing in upstream bioprocessing. Crit. Rev. Biotechnol. 2017, 38, 106-121. [CrossRef]

113. Guerra, A.; Von Stosch, M.; Glassey, J. Toward biotherapeutic product real-time quality monitoring. Crit. Rev. Biotechnol. 2019, 39, 289-305. [CrossRef] [PubMed]

114. Biechele, P.; Busse, C.; Solle, D.; Scheper, T.; Reardon, K. Sensor systems for bioprocess monitoring. Eng. Life Sci. 2015, 15, 469-488. [CrossRef] 
115. Steinwandter, V.; Borchert, D.; Herwig, C. Data science tools and applications on the way to Pharma 4.0. Drug Discov. Today 2019, 24, 1795-1805. [CrossRef]

116. Zhang, A.; Zhu, K.; Zhuang, X.; Liao, L.; Huang, S.; Yao, C.; Fang, B. A robust soft sensor to monitor 1,3-propanediol fermentation process by Clostridium butyricum based on artificial neural network. Biotechnol. Bioeng. 2020, 117, 3345-3355. [CrossRef]

117. Brunner, V.; Klöckner, L.; Kerpes, R.; Geier, D.U.; Becker, T. Online sensor validation in sensor networks for bioprocess monitoring using swarm intelligence. Anal. Bioanal. Chem. 2019, 412, 2165-2175. [CrossRef] [PubMed]

118. Grigs, O.; Bolmanis, E.; Galvanauskas, V. Application of in-situ and soft-sensors for estimation of recombinant P. pastoris GS115 biomass concentration: A case analysis of $\mathrm{HBcAg}\left(\mathrm{Mut}^{+}\right)$and $\mathrm{HBsAg}\left(\mathrm{Mut}^{\mathrm{S}}\right)$ production processes under varying conditions. Sensors 2021, 21, 1268. [CrossRef] [PubMed]

119. Pappenreiter, M.; Sissolak, B.; Sommeregger, W.; Striedner, G. Oxygen uptake rate soft-sensing via dynamic kLa computation: Cell volume and metabolic transition prediction in mammalian bioprocesses. Front. Bioeng. Biotechnol. 2019, 7, 195. [CrossRef]

120. Bayer, B.; Von Stosch, M.; Melcher, M.; Duerkop, M.; Striedner, G. Soft sensor based on 2D-fluorescence and process data enabling real-time estimation of biomass in Escherichia coli cultivations. Eng. Life Sci. 2020, 20, 26-35. [CrossRef] [PubMed]

121. Gopakumar, V.; Tiwari, S.; Rahman, I. A deep learning based data driven soft sensor for bioprocesses. Biochem. Eng. J. 2018, 136, 28-39. [CrossRef]

122. Kornecki, M.; Strube, J. Process analytical technology for advanced process control in biologics manufacturing with the aid of macroscopic kinetic modeling. Bioengineering 2018, 5, 25. [CrossRef] [PubMed]

123. Steinwandter, V.; Zahel, T.; Sagmeister, P.; Herwig, C. Propagation of measurement accuracy to biomass soft-sensor estimation and control quality. Anal. Bioanal. Chem. 2016, 409, 693-706. [CrossRef] [PubMed]

124. Zabadaj, M.; Chreptowicz, K.; Mierzejewska, J.; Ciosek, P. Two-dimensional fluorescence as soft sensor in the monitoring of biotransformation performed by yeast. Biotechnol. Prog. 2016, 33, 299-307. [CrossRef] [PubMed]

125. Baradez, M.-O.; Biziato, D.; Hassan, E.; Marshall, D. Application of Raman Spectroscopy and Univariate Modelling as a Process Analytical Technology for Cell Therapy Bioprocessing. Front. Med. 2018, 5, 47. [CrossRef]

126. Bhatia, H.; Mehdizadeh, H.; Drapeau, D.; Yoon, S. In-line monitoring of amino acids in mammalian cell cultures using raman spectroscopy and multivariate chemometrics models. Eng. Life Sci. 2018, 18, 55-61. [CrossRef]

127. Brestrich, N.; Briskot, T.; Osberghaus, A.; Hubbuch, J. A tool for selective inline quantification of co-eluting proteins in chromatography using spectral analysis and partial least squares regression. Biotechnol. Bioeng. 2014, 111, 1365-1373. [CrossRef] [PubMed]

128. Capito, F.; Skudas, R.; Kolmar, H.; Hunzinger, C. At-line mid infrared spectroscopy for monitoring downstream processing unit operations. Process. Biochem. 2015, 50, 997-1005. [CrossRef]

129. Krishna, V.V.S.V.; Pappa, N.; Rani, S.P.J.V. Deep Learning based Soft Sensor for Bioprocess Application. In Proceedings of the 2021 IEEE Second International Conference on Control, Measurement and Instrumentation (CMI), Kolkata, India, 8-10 January 2021; Institute of Electrical and Electronics Engineers (IEEE): Piscataway, NJ, USA, 2021; pp. 155-159.

130. Hrnčiř́ik, P.; Moucha, T.; Mareš, J.; Náhlík, J.; Janáčová, D. Software sensors for biomass concentration estimation in filamentous microorganism cultivation process. Chem. Biochem. Eng. Q. 2019, 33, 141-151. [CrossRef]

131. Hausmann, R.; Henkel, M.; Hecker, F.; Hitzmann, B. Present Status of automation for industrial bioprocesses. Curr. Dev. Biotechnol. Bioeng. 2017, 2017, 725-757. [CrossRef]

132. Alarcon, C.; Shene, C. Fermentation 4.0, a case study on computer vision, soft sensor, connectivity, and control applied to the fermentation of a thraustochytrid. Comput. Ind. 2021, 128, 103431. [CrossRef]

133. Das, P.; Mishra, S.; Nayak, B. The colossal role of QbD and PAT tools in the pharmaceutical process automation. Int. J. Pharma Res. Health Sci. 2017, 5, 1909-1923.

134. Jiang, M.; Severson, K.A.; Love, J.; Madden, H.; Swann, P.; Zang, L.; Braatz, R.D. Opportunities and challenges of real-time release testing in biopharmaceutical manufacturing. Biotechnol. Bioeng. 2017, 114, 2445-2456. [CrossRef] [PubMed]

135. Zhao, L.; Fu, H.-Y.; Zhou, W.; Hu, W.-S. Advances in process monitoring tools for cell culture bioprocesses. Eng. Life Sci. 2015, 15, 459-468. [CrossRef]

136. Chopda, V.R.; Gomes, J.; Rathore, A.S. Bridging the gap between PAT concepts and implementation: An integrated software platform for fermentation. Biotechnol. J. 2016, 11, 164-171. [CrossRef]

137. Priyanka; Kumar, J.; Gomes, J.; Rathore, A.S.; Dalal, P. Implementing process analytical technology for the production of recombinant proteins in Escherichia coli using an advanced controller scheme. Biotechnol. J. 2019, 14, e1800556. [CrossRef]

138. Jenzsch, M.; Bell, C.; Buziol, S.; Kepert, F.; Wegele, H.; Hakemeyer, C. Trends in process analytical technology: Present state in bioprocessing. Blue Biotechnol. 2017, 165, 211-252. [CrossRef]

139. Ryder, A.G. Cell culture media analysis using rapid spectroscopic methods. Curr. Opin. Chem. Eng. 2018, 22, 11-17. [CrossRef]

140. Schmid, I.; Aschoff, J. A scalable software framework for data integration in bioprocess development. Eng. Life Sci. 2016, 17, 1159-1165. [CrossRef]

141. Whitford. The era of digital biomanufacturing. BioProcess Int. 2017, 15(3), 12-18.

142. Tung, G.; Morris, K.; Perrone, P.; Reinbigler, R.; Miller, S.; Lai, C. The value of plug-and-play automation in single-use technology. BioProcess Int. 2019, 17, 12-19. 
143. Feidl, F.; Vogg, S.; Wolf, M.; Podobnik, M.; Ruggeri, C.; Ulmer, N.; Wälchli, R.; Souquet, J.; Broly, H.; Butté, A.; et al. Process-wide control and automation of an integrated continuous manufacturing platform for antibodies. Biotechnol. Bioeng. 2020, 117, 1367-1380. [CrossRef]

144. CFR 21 Part 11-Food and Drug Administration (FDA) Guidelines on Electronic Records and Electronic Signatures; US FDA: Montgomery, MD, USA, 2003

145. Charan, H.Y.; Gupta, N.V. Gamp 5 a Quality Risk Management Approach to Computer System Validation. Int. J. Pharm. Sci. Rev. Res. 2016, 36, 195-198. 